\title{
Evaluation between vitamin D serum level and Herpes Simplex Virus Type 1 in the field of dentistry
}

\author{
- Parvin Parvaie Department of Oral and Maxollofacial Medicine, School of Dentistry, Birjand University of Medical \\ Sciences, Birjand, Iran • Saideh Ebrahimian Baghan Student Research Committee, Birjand University of Medical \\ Sciences, Birjand, Iran - Freshteh Osmani Infectious Disease Research Center, Birjand University of Medical \\ Sciences, Birjand, Iran
}

ABSTRACT | ABSTRACT | Objectives: Our study sought to evaluate the association between HSV1 and serum 25-hydroxyvitamin D (25(OH) D) levels among dental students. Materials \& Methods: This is a cross-sectional study with a quantitative approach conducted in Birjand, state of Khorasan Jonoobi, Iran, from July 2018 to April 2019. A peripheral blood sample $(5 \mathrm{ml})$ and an anti-virus antibody along with Serum 25-hydroxyvitamin D $(1,25(\mathrm{OH}) 2 \mathrm{D} 3)$ levels were measured using an Anti-Herpes-1 IgG kit with ELISA by a pathologist. Pearson and chi-square tests were applied in the significance level of $5 \%$. Results: The prevalence of HSV1 was $41 \%$. The serum 25-hydroxyvitamin D3 levels mean was $23.22 \pm 13.09$. The prevalence of HSV1 antibody in pre-clinical and clinical levels was higher than in basic science, also, the results represented that a negative relation between vitamin D deficiency and the presence of HSV1, but it was not a significant association. Conclusion: Any association between vitamin D and herpes viruses remains inconclusive. Further studies in the general population are needed.

\section{DESCRIPTORS | Herpesvirus; Vitamin D Deficiency; Dentistry.}

RESUMO | Avaliação entre o nível sérico de vitamina D e Herpes Simplex Vírus tipo 1 no domínio da odontologia • Objetivo: Esse estudo teve por objetivo avaliar a associação entre os níveis séricos de 25-hidroxivitamina D (25[OH]D) e o Herpes Simplex Vírus tipo 1 (HSV1) em estudantes de odontologia. Materiais e métodos: Trata-se de um estudo transversal com abordagem quantitativa realizado em Birjand, Khorasan Jonoobi, Irã, entre julho de 2018 e abril de 2019. Utilizando o kit AntiHSV1 método ELISA, uma amostra de sangue periférico $(5 \mathrm{~mL})$ e um anticorpo anti-vírus com 25-hidroxivitamina D sérica $(1,25[\mathrm{OH}] 2 \mathrm{D} 3)$ foram examinadas por um patologista. Os testes qui-quadrado e de Pearson foram calculados considerando um nível de significância igual a 5\%. Resultado: A prevalência do HSV1 foi de $41 \%$ e a média dos níveis séricos de 25-hidroxivitamina D3 foi igual a 23,22 \pm 13,09. A prevalência de anticorpos HSV1 em níveis pré-clínicos e clínicos foi maior do que o reportado na ciência básica. Além disso, os resultados indicam uma relação negativa entre a deficiência de vitamina $\mathrm{D}$ e a presença de HSV1, embora não seja uma associação significativa. Conclusão: Qualquer associação entre a vitamina D e os vírus do herpes permanece inconclusiva, de forma que mais estudos com a população em geral são necessários.

DESCRITORES | Herpesvírus; Deficiência de Vitamina D; Odontologia.

CORRESPONDING AUTHOR | Freshteh Osmani Infectious Disease Research Center, Birjand University of Medical Sciences • Ghafari Street Birjand, Iran • 9717853577 E-mail: dr.osmani68@gmail.com

- Received February 21, 2021 • Accepted July 10, 2021 


\section{INTRODUCTION}

The antiviral and immunomodulatory role of vitamin $\mathrm{D}$ has been shown in various viral infections. The recrudescence of HSV infections requires simultaneously viral reactivation at the trigeminal ganglia level. ${ }^{1}$

Vitamin D is synthesized by the skin after sunlight exposure, or it can also be consumed through food or supplements. Its concentration in the blood is greatly affected by season and latitude, as well as by nutritional intake. Vitamin D deficiency may lead to rickets in children or osteomalacia in adults. ${ }^{2}$

Some studies have shown that this vitamin may have some immunomodulatory effects and antiinfective potential, and at a cellular level, vitamin D regulates the production of the antimicrobial peptide cathelicidin.

Also, among epidemiological studies, a metaanalysis showed that the risk of infection was lower in chronic kidney disease patients with normal or higher serum vitamin D levels. ${ }^{3}$

However, whether vitamin D is associated with protection against herpes viruses is still unclear, and there is no comprehensive review of this possible association. As vitamin D supplementation is an inexpensive public health intervention, studying its possible association with herpes viruses may help us find a novel approach to mitigate the health impact of these infectious diseases.

Because of their ability to establish latent infections with intermittent shedding, particularly in the oral cavity and perioral regions, dental surgeons and allied personnel are likely to be at risk. ${ }^{4}$

Also, the prevalence of infections in the dental profession is high, since these people are more exposed to blood, saliva, and risk of cuts. ${ }^{5}$ The frequency of herpetic whitlow is higher among practicing dentists compared to the normal population. ${ }^{6}$ However, reports confirming the transmission of infection from the patient to the dental team infection are available in the literature. ${ }^{5} \mathrm{~A}$ dental hygienist with herpetic whitlow, who did not use gloves routinely, infected 20 out of 46 patients. $^{7}$

However, there is scanty literature available about the effect of vitamin D supplementation in herpes simplex virus-1 (HSV-1) infection. Therefore, this study sought to determine the prevalence of antibodies to herpes simplex virus type 1 (HSV l) and also to investigate the relation between serum vitamin $\mathrm{D}$ levels or oral vitamin D supplementation and the risk of HSV1 infection in dental students in 2018-2019.

\section{MATERIALS AND METHODS}

In the current study, dental students of Birjand University of Medical Sciences were included voluntarily. The study excluded: those who had taken vitamin D supplements in the previous 12-month period; those with systemic diseases of the liver, kidney, cardiovascular system, or digestive system; and those who used steroids or other immunemodulating drugs.

As result, the sample consisted of 100 students, divided according to the student's level, from 3 different levels (basic sciences, pre-clinical, clinical). Each subject completed a questionnaire. Demographic data and details of medical background were collected, including a history of previous blood transfusion, history of genital or oral lesions, and use of any antiviral or immunosuppressive drugs. The qualified dental surgeons were also asked questions regarding the number of years they had been in practice and the number of needle stick injuries suffered. A $5 \mathrm{ml}$ sample of peripheral blood was collected. The serum was separated and stored at $-28^{\circ} \mathrm{C}$ before the serological testing. Then, the presence of anti-virus antibody was then evaluated by a pathologist using a dedicated Anti-Herpes-1 IgG kit and by an Enzyme-Linked Immunosorbent Assay (ELISA) method.

\section{Serum vitamin D levels}

For 25(OH)D (from here on vitamin $\mathrm{D}$ ) analysis, a 5 - $\mathrm{mL}$ sample of forearm venous blood was taken 
into anticoagulant biochemical tubes. Blood samples were centrifuged at $1,000 \mathrm{rpm}$ for $15 \mathrm{~min}$ to obtain serum samples. Sera were stored at $-80 \mathrm{C}$ for 6 months until analysis.

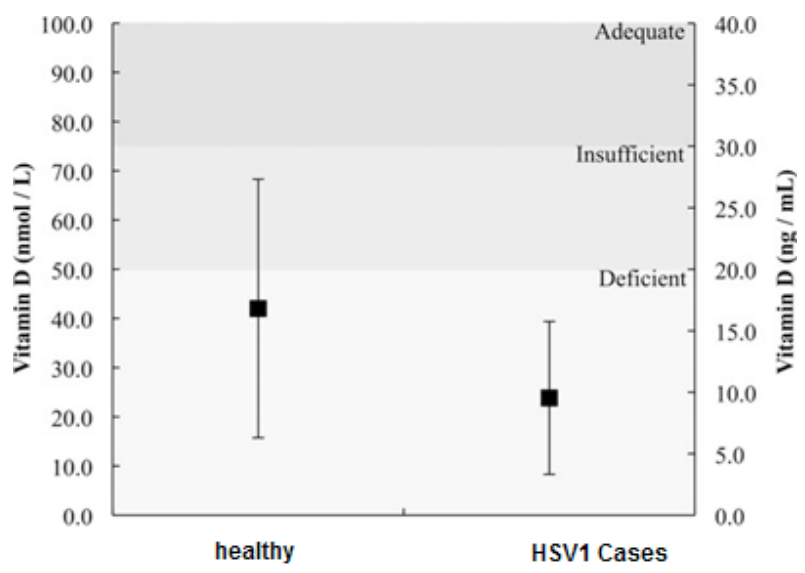

FIGURE. 1 | Serum vitamin D levels in the Studies Groups. Error bars represent \pm Standard Deviation.

\section{Statistical evaluation}

Continuous variables were presented as mean \pm standard deviation. Analysis between the groups and the variables was performed by using the Student's t-test and chi-squared test Correlations between numerical parameters were evaluated with Spearman's rank correlation coefficient. The level of statistical significance was set at $\mathrm{p}<0.05$. Statistical analyses of the data were conducted using SPSS program (v24; SPSS, Inc., Chicago).

\section{RESULTS}

A total of 100 individuals were included in the study with a mean age of $22.8 \pm 3.9$ ranging from 18 to 29 , with 43 males and 57 females. Table 1 shows the demographic characteristics of the sample. The average serum vitamin $\mathrm{D}$ level in the study sample, as a whole, was $13.2 \pm 9.4 \mathrm{ng} / \mathrm{mL}$, which meant that more than $96 \%$ of the population had serum vitamin $\mathrm{D}$ below the adequate level.
TABLE 1 || Frequency Distribution of Demographic Characteristics in the Study Participants.

\begin{tabular}{|c|c|c|c|}
\hline Variable & & $\begin{array}{c}\text { Absolute } \\
\text { Frequency }\left(n^{\circ}\right)\end{array}$ & $\begin{array}{c}\text { Relative } \\
\text { Frequency (\%) }\end{array}$ \\
\hline \multirow{2}{*}{ Sex } & Male & 43 & 43 \\
\hline & Female & 57 & 57 \\
\hline Age & Mean \pm SD & $22 \pm 1.39$ & \\
\hline \multirow{2}{*}{ Marital status } & Single & 87 & 87 \\
\hline & Married & 13 & 13 \\
\hline \multirow{2}{*}{$\begin{array}{l}\text { Educational } \\
\text { level }\end{array}$} & College phase & 61 & 33 \\
\hline & Clinical & 36 & 36 \\
\hline \multirow{2}{*}{$\begin{array}{l}\text { History of } \\
\text { herpes }\end{array}$} & Yes & 31 & 31 \\
\hline & No & 69 & 69 \\
\hline \multirow{2}{*}{$\begin{array}{l}\text { History of } \\
\text { antiviral drugs }\end{array}$} & Yes & 1 & 1 \\
\hline & No & 99 & 99 \\
\hline \multirow{2}{*}{$\begin{array}{l}\text { Antibody Titer } \\
\text { status }\end{array}$} & Negative & 59 & 59 \\
\hline & Positive & 41 & 41 \\
\hline
\end{tabular}

According to the results of Table 1, $31 \%$ of the students had a history of herpes and $1 \%$ had a history of taking antiviral drugs.

The mean of IgG titer in the students was $16.1 \pm 17.2$ and $59 \%$ had negative antibody titer.

TABLE 2 | Comparison of IgG antibody Titer Mean by Demographic Variables in Students.

\begin{tabular}{|c|c|c|c|}
\hline $\begin{array}{l}\text { Antibody titer } \\
\text { status Variable }\end{array}$ & & Mean \pm SD & $\begin{array}{l}\text { Mann-Whitney or } \\
\text { Kruskal-Wallis test }\end{array}$ \\
\hline \multirow{2}{*}{ Sex } & Male & $17.97 \pm 2.94$ & \multirow{2}{*}{$\begin{array}{c}Z=67 \\
P=0.51\end{array}$} \\
\hline & Female & $16.37 \pm 2.17$ & \\
\hline \multirow{3}{*}{ Age } & $<21$ & $16.1 \pm 17.42$ & \multirow{3}{*}{$\begin{array}{c}\lambda^{2}=0.53, d f=2 \\
P=0.77\end{array}$} \\
\hline & $22-24$ & $15.1 \pm 16.73$ & \\
\hline & $>25$ & $17.77 \pm 18.2$ & \\
\hline \multirow{2}{*}{ Marital status } & Single & $16.16 \pm 17.22$ & \multirow{2}{*}{$\begin{aligned} Z & =0.08 \\
P & =0.94\end{aligned}$} \\
\hline & Married & $15.5 \pm 17.67$ & \\
\hline \multirow[t]{2}{*}{ Educational level } & $\begin{array}{l}\text { College } \\
\text { phase }\end{array}$ & $14.59 \pm 16.77$ & \multirow{2}{*}{$\begin{array}{c}\lambda^{2}=0.09, d f=2 \\
P=0.95\end{array}$} \\
\hline & Clinical & $16.1 \pm 17.6$ & \\
\hline \multirow{2}{*}{ History of herpes } & Yes & $38.8 \pm 12.69$ & \multirow{2}{*}{$\begin{array}{c}Z=5.91 \\
P<0.001\end{array}$} \\
\hline & No & $33.2 \pm 13.1$ & \\
\hline
\end{tabular}

According to Table 2, no statistically significant difference was observed in the mean IgG titer in terms of gender, marital status, educational level, and age in 
the studied students ( $\mathrm{P}>0.05)$, but IgG antibody titer in students with a history of herpes was significantly higher than in students without it $(\mathrm{p}<0.001)$.

TABLE 3 | Vitamin D Levels in the Study Group.

\begin{tabular}{c|c}
\hline Vitamin D status & $\begin{array}{c}\text { Frequency } \\
(\%)\end{array}$ \\
\hline $\begin{array}{c}\text { Deficient } \\
(<\mathbf{5 0} \mathbf{n M})\end{array}$ & $67(67)$ \\
\hline $\begin{array}{c}\text { Insufficient } \\
(<\mathbf{7 5} \mathbf{n M})\end{array}$ & $21(21)$ \\
\hline $\begin{array}{c}\text { Adequate } \\
\text { (\$75 nM) }\end{array}$ & $12(12)$ \\
\hline
\end{tabular}

No significant correlation was found between having HSV1 and the vitamin D levels (Spearman's $\mathrm{r}=0.036, \mathrm{p}=0.805)$.

A significant difference was found between the cases with HSV1 and healthy students in terms of both the average serum vitamin D levels $(\mathrm{p}<0.001)$ and the vitamin $\mathrm{D}$ adequacy status ( $\mathrm{p}=0.003$ ).

There was a statistically significant difference in risk of HSV1 amongst participants with a deficiency level of vitamin D3 compared to other levels $(P=0.02)$.

Among all cases, 67\% had deficient vitamin D3 levels and only12 \% had adequate levels (Table3).

\section{DISCUSSION}

HSV1 infection are pervasive in all parts of the world. Vitamin D has been shown to play a pivotal role in the regulation of innate and adaptive immunity. ${ }^{8,9}$ In this study, having HSV1 was found to be associated with lower levels of serum vitamin D. However, in this sample these levels were nearly low, generally, none of the HSV1 cases had adequate levels of serum vitamin D. This suggests that having adequate levels of vitamin D may contribute to mounting a powerful immune response against HSV1 infections. This finding is in support of a study, which demonstrated that vitamin D supplementation in two forms downregulated the HSV1, mRNA and DNA. Different studies show an association between lower vitamin D levels and increased presence of infectious diseases. In line with the results of this study, vitamin D has been suggested to contribute to the protection against seasonal influenza A infection. ${ }^{10}$

This deficiency is an important issue, but this study did not address this subject, as we did not collect data on the factors such as dietary habits of students, which are known to affect serum vitamin D levels. The city where the study was conducted is in a religiously part of the country, which may affect their clothing and sun exposure practices, leading to lower levels of vitamin D.

The results of this study showed that the majority of students had negative antibody titer. Other studies showed similar results. ${ }^{711}$ Some studies have reported different results. ${ }^{12-14}$ The difference in antibody titer may be due to social situations in different parts of these surveys. According to the results of the present study, the mean of HSV1 antibody titer in different age groups increased with age but this difference wasn't significant. Another finding of this study showed that there was no significant relationship between gender and HSV1 antibody titers. Other studies presented similar results . ${ }^{11,15}$ This study demonstrated the effects of deficiency of vitD3 on the risk of positive HSV1 too. Another study indicated that vitD3 administration may be useful as a complementary therapeutic option for the treatment of inflammatory diseases. ${ }^{4}$

\section{CONCLUSIONS}

In conclusion, this study found a serious vitamin $\mathrm{D}$ deficiency in the studied population regardless of their infection status. The study also demonstrated a significant relationship between low levels of circulating vitamin D metabolites and the presence of $\mathrm{RH}$. More research is warranted for clarifying the degree of association, seasonal variations, the mechanism of the relationship, and whether the relationship is causative or not. It is also recommended that studies be designed wider and with more samples. The study also demonstrated a 
significant relation between low levels of circulating vitamin D metabolites and the presence of HTLV1.

\section{ACKNOWLEDGEMENTS}

We would like to thank the Clinical Research Development Center, Birjand University of Medical Sciences for its consulting and cooperation in the conduction of this research in the form of a doctoral dissertation.

\section{REFERENCE}

1. Chiang KC, Yeh CN, Chen MF, Chen TC. Hepatocellular carcinoma and vitamin D: a review. J Gastroenterol Hepatol. 2011;26(11):1597-603. Doi: https://doi.org/10.1111/j.14401746.2011.06892.x

2. Osmani F. Effect evaluation of vitamin D level amongst patients with chronic hepatitis B. Arch Pathol Clin Res. 2019;3:20-1. Doi: https://doi.org/10.29328/journal.apcr.1001014

3. Osmani F, Ziaee M. Assessment of the risk factors for vitamin D3 deficiency in chronic hepatitis B patient using the decision tree learning algorithm in birjand. Inform Med Unlocked. 2021;23:100519. Doi: https://doi.org/10.1016/j. imu.2021.100519

4. Osmani F, Hajizadeh E, Rasekhi A, Akbari ME. Prognostic factors associated with locoronal relapses, metastatic relapses, and death among women with breast cancer. Populationbased cohort study. Breast. 2019;48:82-8. Doi: https://doi. org/10.1016/j.breast.2019.09.010

5. Fujii H, Nakai K, Yonekura Y, Kono K, Goto S, Hirata M, et al. The vitamin D receptor activator maxacalcitol provides cardioprotective effects in diabetes mellitus. Cardiovasc Drugs Ther. 2015;29(6):499-507. Doi: https://doi.org/10.1007/ s10557-015-6629-y

6. Ghaziasadi A, Ziaee M, Norouzi M, Malekzadeh R, Alavian SM, Saberfar E, et al. The prevalence of hepatitis B virus surface antigen (HBsAg) variations and correlation with the clinical and serologic pictures in chronic carriers from Khorasan Province, North-East of Iran. Acta Med Iran. 2012;50(4):265-72. 7. Heshmat R, Mohammad K, Majdzadeh S, Forouzanfar M, Bahrami A, Ranjbar Omrani G, et al. Vitamin D deficiency in Iran: A multi-center study among different urban areas. Iran J Public Health. 2008;37(1):72-8.

8. Osmani M, Osmani F, Pourhoseingholi MA. Comparison of Decision Tree and Logistic Regression for Prediction of Functional Dyspepsia and Gastroesophageal Reflux Disease in Tehran Province Using Rome III. Mod Care J. 2019;16(4):e94669. Doi: https://doi.org/10.5812/modernc.94669

9. Parvaie P, Majd HS, Ziaee M, Sharifzadeh G, Osmani F. Evaluation of gum health status in hemophilia patients in Birjand (a case-control study). Am J Blood Res. 2020;10(3):54-9.

10. Azarkar G, Doosti Z, Osmani F, Ziaee M. Analysis Of Risk Factors For Nonalcoholic Fatty-Liver Disease In Hepatitis B Virus Infection: A Case-Control Study. Hepat Med. 2019;11:153-8.

11. Hoan NX, Khuyen N, Binh MT, Giang DP, Van Tong H, Hoan $P Q$, et al. Association of vitamin D deficiency with hepatitis B virus-related liver diseases. BMC Infect Dis. 2016;16(1):507. Doi: https://doi.org/10.1186/s12879-016-1836-o

12. Rezaei-Chaparpordi S,Assmar M, Amirmozafari N, Modiri L, Massiha A, Gholizadeh Z. Seroepidemiology of Herpes Simplex Virus Type 1 and 2 in Anzali city 2010-2011. Zahedan J Res Med Sci. 2012;14(8):67-9.

13. Androutsakos T, Sipsas N, Kontos A, Hatzis G. HCV treatment in $\mathrm{HIV} / \mathrm{HCV}$ co-infected patients A single center, observational study. Arch Hell Med. 2019;36(6):787-91.

14. Osmani F, Azarkar G. Fitting logistic regression models to assess vitamin $\mathrm{D}$ deficiency with clinical parameters in chronic hepatitis B patients. Infect Dis Model. 2021;6:612-7. Doi: https://doi.org/10.1016/j.idm.2021.03.008

15. Hu YC, Wang WW, Jiang WY, Li CQ, Guo JC, Xun YH. Low vitamin D levels are associated with high viral loadas in patients with chronic hepatitis B: A systematic review and meta-analysis. BMC Gastroenterol. 2019;19(1):84. 